Vol. 2 No. 1 (2019)

\title{
DINAMIKA KEBIJAKAN KETERLIBATAN INDONESIA DALAM KERJASAMA SELATAN-SELATAN (KSS) PERIODE 2004-2018
}

\author{
Rahmadian Paramita \\ Departemen Ilmu Hubungan Internasional, Fakultas Ilmu Sosial dan Ilmu Politik, \\ Universitas Indonesia \\ rahmadianparamita@gmail.com
}

\begin{abstract}
Indonesia is a middle-income country that is no longer only a foreign aid recipient but also a provider in South-South Cooperation (SSC). The shift in global economic power encourage Indonesia to continue enhancing relations with developing countries in SSC, but this cannot necessarily be done because of the factors that affect Indonesia's foreign policy, both from external and internal Indonesia. The purpose of this study is to describe the dynamics of Indonesian policy involving in the SSC in the period of 20042018. This study uses qualitative approach with data collection techniques through official government sites and literature studies from other sources. The results indicate that there are factors affecting the differences of foreign policy of each leader. External factors make the policy of President Susilo Bambang Yudhoyono (SBY) emphasizes more on good relations with anyone, especially developed countries because SSC is not a top priority. Internal factors influencing President SBY's policy emphasize on increasing Indonesia's status in every field. While President Joko Widodo's (Jokowi's) policy regarding external factors emphasizes more on relations with developing countries because it's one of the main priorities of his government. Internal factors make President Jokowi's policies focus more on resources utilization possessed by Indonesia.
\end{abstract}

Keywords: Foreign Policy, Joko Widodo, South-South Cooperation, Susilo Bambang Yudhoyono

\begin{abstract}
Abstrak
Indonesia merupakan negara middle income yang bukan lagi hanya sebagai beneficiary bantuan tetapi juga provider dalam Kerjasama Selatan-Selatan (KSS). Pergeseran kekuatan dunia mendorong Indonesia untuk terus mempekuat hubungan dengan negaranegara berkembang dalam KSS, namun hal tersebut tidak serta merta dapat dilakukan karena terdapat faktor-faktor yang mempengaruhi kebijakan luar negeri Indonesia, baik dari eksternal maupun internal Indonesia. Tujuan penelitian ini adalah untuk mendeskripsikan dinamika kebijakan keterlibatan Indonesia dalam KSS periode 20042018. Penelitian ini menggunakan pendekatan kualitatif dengan teknik pengumpulan data melalui berbagai website resmi pemerintah Indonesia dan studi kepustakaan dari sumber-sumber lain. Hasil penelitian ini menunjukkan bahwa terdapat faktor-faktor yang mempengaruhi perbedaan kebijakan keterlibatan Indonesia dalam KSS pada setiap pemimpin. Faktor-faktor eksternal membuat kebijakan Presiden Susilo Bambang Yudhoyono (SBY) lebih menekankan pada hubungan baik dengan siapa saja, terutama negara maju karena KSS bukan prioritas utama. Faktor-faktor internal mempengaruhi kebijakan Presiden SBY menekankan pada peningkatan status Indonesia secara merata di hampir setiap bidang. Sementara kebijakan Presiden Joko Widodo (Jokowi) terkait
\end{abstract}


kondisi faktor-faktor eksternalnya tergolong lebih menekankan pada hubungan dengan negara-negara berkembang karena termasuk ke dalam salah satu prioritas utama pemerintahannya. Faktor-faktor internal membuat kebijakan Presiden Jokowi lebih mengarah pada pemanfaatan sumber daya yang dimiliki Indonesia.

Kata kunci: Joko Widodo; Kebijakan Luar Negeri; Kerjasama Selatan-Selatan; Susilo Bambang Yudhoyono

\section{Pendahuluan}

Indonesia merupakan negara yang pada tahun 2008 menyandang status lowermiddle income country. Indonesia juga merupakan ekonomi terbesar di Kawasan Asia Tenggara dengan jumlah populasi yang juga terbesar, yaitu 240 juta jiwa pada sensus penduduk tahun 2010. Walaupun demikian, Indonesia masih banyak menerima bantuan pembangunan luar negeri

Tabel 1.1

Nominal Official Development Assistance (ODA) Bruto kepada Indonesia dari Pendonor Resmi (dalam juta USD)

\begin{tabular}{|c|c|c|c|c|c|c|}
\hline Tahun & 2012 & 2013 & 2014 & 2015 & 2016 & 2017 \\
\hline Jumlah & $2.324,93$ & $2.447,48$ & $2.123,74$ & $2.035,97$ & $2.119,77$ & $2.431,59$ \\
\hline
\end{tabular}

Sumber: Diolah dari Organization of Economic Co-operation and Development (OECD) (2018a)

Jika dilihat dari Tabel 1.1 di atas, ODA bruto dari donor resmi ke Indonesia cenderung tidak mengalami perubahan yang signifikan. Selama enam tahun, sejak tahun 2012 hingga tahun 2017, nominal ODA bruto tersebut hanya turun di tahun 2014 dan 2015. Jumlah total ODA bruto ke Indonesia dari tahun 2012 hingga tahun 2017 dalam kategori lokasi Far East Asia merupakan jumlah ODA bruto terbesar kedua setelah Vietnam (OECD, 2018). Rata-rata penerimaan ODA bruto Indonesia pada tahun 2013-2014 merupakan jumlah terbesar kelima di dunia (OECD, 2016a). Hal tersebut membuktikan bahwa Indonesia masih terus membutuhkan ODA dari para pendonor.

Namun demikian, walaupun masih menerima bantuan dari berbagai pihak, Indonesia juga memberikan bantuan luar negeri kepada negara lain. Analis ekonomi memasukkan Indonesia sebagai emerging economy karena keberhasilannya dalam pertumbuhan ekonomi yang sangat cepat, bahkan angka pertumbuhannya melebihi negara-negara maju. Pada tahun 2011, Indonesia merupakan ekonomi terbesar ke-10 dunia dengan share Gross Domestic Bruto (GDP) Indonesia terhadap total GDP dunia mencapai 2,3\% (The Jakarta Post, 2014). Pada tahun 2017, GDP Indonesia tumbuh sebesar 5,07\%, dan tahun 2018 sebesar 5,17\% (World Bank, 2018).

Selain sebagai penerima bantuan dari negara-negara lain di dunia, pada saat yang sama Indonesia memikul tanggung jawab untuk memainkan peran sebagai penyedia bantuan pembangunan. Sebagai salah satu anggota G20, Indonesia memberikan perhatian besar terhadap pembangunan negara-negara berkembang. Bahkan jauh sebelum G20 memberikan perhatian pada agenda pembangunan di tahun 2010, Indonesia telah berperan 
dalam Kerjasama Selatan-Selatan (KSS) atau South-South Cooperation.

Indonesia telah mengeluarkan sekitar USD 42 juta dalam bentuk bantuan luar negeri selama tahun 2002 hingga tahun 2012. Aliran bantuan kerjasama pembangunan Indonesia yang disalurkan lewat organisasi multilateral mencapai USD 129 juta pada tahun 2016. Nilai tersebut meningkat dari tahun 2015 yang hanya mencapai USD 14,2 juta (OECD, 2018b). Tabel 1.2 berikut menunjukkan bahwa sejak tahun 2010 hingga 2014, aliran dana untuk pembangunan dari Indonesia terus meningkat secara signifikan. Dengan demikian, setiap tahun Indonesia semakin memperbesar jumlah aliran dana ke luar negeri untuk pembangunan. Indonesia bekerjasama secara bilateral dengan sekitar 40 negara mitra yang sebagian besar merupakan negara-negara di Asia dalam berbagai sektor, khususnya beasiswa dan proyek kerjasama teknis (OECD, 2018b).

Tabel 1.2

Aliran Bruto dari Indonesia untuk Kerjasama Pembangunan 2010-2014 (dalam juta USD)

\begin{tabular}{|c|c|c|c|c|c|c|c|}
\hline Tahun & 2010 & 2011 & 2012 & 2013 & 2014 & 2015 & 2016 \\
\hline Jumlah & 10 & 16 & 26 & 49 & 56 & 14,2 & 129 \\
\hline
\end{tabular}

Sumber: Diolah dari OECD (2016b) dan OECD (2018b)

Indonesia merupakan negara yang tergabung dalam KSS yang bertujuan untuk lebih mengedepankan kepentingan negara-negara berkembang. Salah satunya dengan memberikan bantuan luar negeri dalam bidang ekonomi. Beberapa bantuan luar negeri yang diberikan Indonesia dalam KSS antara lain bantuan yang diberikan Indonesia pada tahun 2016 di sektor perikanan ke Namibia, Mozambique, Kenya, Madagascar, Sudan, dan Zimbabwe. Selain itu, Indonesia juga memberikan bantuan di sektor pertanian pada tahun 2016 ke Gambia dan Tanzania (Asia News Monitor, 2016). Untuk wilayah Afrika, Indonesia telah melaksanakan 85 program bantuan dengan lebih dari 500 partisipan dalam sektor perikanan, pertanian dan kesehatan. Sejak tahun 1999, Indonesia telah mengimplementasikan lebih dari 460 program pengembangan kapasitas (capacity building) untuk lebih dari 5.400 partisipan dari Asia, Afrika, Pasifik, dan Timur Tengah (Asia
Monitor, 2016). Indonesia juga banyak memberikan bantuan kepada negaranegara anggota KSS, kususnya Kepulauan Pasifik, dalam bentuk bantuan pemulihan bencana.

Indonesia bahkan dianggap sebagai salah satu emerging donor dari Asia Tenggara (ASEAN) (Ishida et. al, 2011). Indonesia merupakan satusatunya negara di Asia Tenggara yang merupakan anggota dari G20 sebagai salah satu dari ekonomi terbesar yang semakin berkembang di dunia. Peran internasional Indonesia semakin berkembang dan Indonesia semakin berkeinginan untuk menjadi penyedia bantuan seutuhnya bagi KSS (Trinidad, 2014: 1-89).

Indonesia memiliki peran dalam perkembangan KSS karena berdasarkan sejarah, Indonesia merupakan salah satu negara penggagas diadakannya Konferensi Asia Afrika (KAA) tahun 1955. Seluruh negara-negara yang terlibat dalam KAA mendeklarasikan keyakinannya bahwa kerjasama yang 
bersahabat akan berkontribusi secara efektif terhadap kedamaian dan keamanan internasional. Selain itu, kerjasama dalam bidang ekonomi, sosial dan budaya akan membawa kesejahteraan dan kemakmuran bagi negara-negara Asia-Afrika. KAA kemudian menjadi pendorong pembentukan Gerakan Non-Blok (GNB) yang meyakini bahwa setiap negara harus memiliki keberanian untuk menentukan nasib dan masa depannya sendiri, termasuk negara-negara berkembang di Asia dan Afrika (Arsip Nasional Republik Indonesia (ANRI) dan (UNESCO), 2015).

Pada masa pemerintahan Presiden Soekarno, fokus dari KSS adalah kerjasama ekonomi, budaya, hak asasi manusia dan diskriminasi, kemandirian, dan perdamaian dunia (Arsip Nasional Republik Indonesia (ANRI) dan (UNESCO), 2015). Namun demikian, kerjasama ekonomi dan teknis ditutupi oleh dominasi politik. Politik antikolonialisme masih sangat terlihat dalam kebijakan luar negeri Indonesia (Center for East Asian Cooperation Studies (CEACos), 2010: 49).

Setelah Gerakan 30 September, Presiden Soeharto memprioritaskan pembangunan ekonomi domestik. Indonesia pada saat itu membutuhkan bantuan dari negara-negara yang memiliki modal dan sumber daya. Pada tahun 1981, Indonesia membangun Indonesian Technical Cooperation Program (ITCP) dengan mengeluarkan Keppres No. 60/1981. Indonesia juga menginisiasikan Kerjasama Teknik Negara Berkembang (KTNB) dengan negara-negara Pasifik Selatan untuk membantu negara-negara berkembang tersebut. Pada tahun 1989, Indonesia menginisiasikan pembangunan kelompok yang beranggotakan 15 negara berkembang atau G-15 untuk memfasilitasi perdagangan, pertukaran teknologi, dan investasi di negaranegara berkembang dalam rangka meningkatkan kekuatan tawar-menawar mereka dalam organisasi internasional (CEACos, 2010: 52-53). Pada dekade terakhir masa pemerintahan Soeharto, Indonesia menjadi pemimpin GNB periode tahun 1992 hingga tahun 1995. Kepemimpinan Indonesia untuk membangun KSS tersebut terwujud pada pembangunan Non-Aligned Movement Centre for South-South Technical Cooperation (NAM-CSSTC) untuk mendorong pembangunan di negara-negara berkembang (CEACos, 2010: 51 \& 56).

Pada masa pemerintahan Habibie, Abdurrahman Wahid, dan Megawati, fokus kebijakan Indonesia dalam keterlibatannya dalam KSS tidak mengalami hal-hal yang signifikan dan cenderung menekankan pada perdagangan dengan negara-negara berkembang. Pada masa pemerintahan Susilo Bambang Yudhoyono (SBY), KSS tidak menjadi prioritas dalam kebijakan luar negeri Indonesia, namun kerjasama teknis antar negara berkembang masih lebih diprioritaskan dibanding pada masa-masa pemerintahan era reformasi sebelumnya. Pada tahun 2005, Kementerian Luar Negeri menjalani proses restrukturisasi dengan adanya pembentukan Direktorat Kerjasama Teknik (KST) yang bertujuan untuk meningkatkan peran aktif Indonesia dalam kerjasama dengan negara-negara berkembang. Indonesia mengarahkan kebijakannya pada formulasi kemitraan yang setara dan berkelanjutan antara negara berkembang dan negara maju atau institusi internasional lainnya lewat South-South Technical Cooperation (SSTC). SBY juga membuat persetujuan-persetujuan internasional 
berkaitan dengan KSS yang bertujuan untuk memperkuat komitmen negaranegara berkembang dalam KSS (Center for East Asian Cooperation Studies (CEACos), 2010: 64-67).

Pada masa pemerintahan Presiden Joko Widodo (Jokowi), di dalam Nawa Cita, terdapat misi untuk meningkatkan peran Indonesia secara regional dan global sebagai negara middle power. $\mathrm{Di}$ dalam Rencana Pembangunan Jangka Menengah Nasional (RPJMN) Indonesia 2015-2019 disebutkan bahwa pusat ekonomi dunia ke depan diperkirakan akan bergeser terutama dari kawasan Eropa-Amerika ke kawasan Asia-Pasifik. Pertumbuhan negara berkembang yang tinggi akan mengakibatkan negara berkembang menjadi motor penggerak pertumbuhan ekonomi dunia. Dengan demikian, dalam rangka memperkuat peran Indonesia dalam kerjasama global dan regional, Jokowi juga mencantumkan peningkatan pelaksanaan kerjasama pembangunan sebagai salah satu sasaran yang ingin dicapai dalam RPJMN 20152019 (Kementerian Perencanaan Pembangunan Nasional/Badan Perencanaan Pembangunan Nasional, 2014).

Berdasarkan penjelasan mengenai kebijakan keterlibatan Indonesia dalam KSS sejak awal kemerdekaan sampai sekarang, terdapat perubahan-perubahan yang terjadi dalam kebijakannya. Dinamika kebijakan-kebijakan tersebut dipengaruhi oleh faktor-faktor yang menarik untuk diteliti. Dalam tulisan ini, akan diteliti mengenai faktor-faktor yang mempengaruhi dinamika kebijakan keterlibatan Indonesia dalam KSS periode sejak tahun 2004 hingga tahun 2018 untuk mempermudah proses pengumpulan data. Berdasarkan penjelasan di atas, maka tujuan dari penelitian ini adalah untuk mengetahui faktor-faktor yang mempengaruhi kebijakan keterlibatan Indonesia dalam KSS periode 2004-2018.

Untuk menganalisis dan menjawab pertanyaan dalam tulisan ini, penulis menggunakan teori kebijakan luar negeri (foreign policy) untuk lebih memahami definisi dan faktor-faktor yang mempengaruhi kebijakan luar negeri. Pembuatan keputusan mengenai kebijakan luar negeri diyakini sebagai instrumen penting bagi suatu negara untuk mengejar kepentingan nasionalnya. AS (2018: 2) mengemukakan bahwa kebijakan luar negeri meliputi tiga bagian, yaitu bagian "akhir", bagian "jalan", dan bagian "cara". Bagian akhir mencakup visi mengenai hasil yang ingin dicapai atau seperangkat kepentingan dalam berinteraksi dengan negara lain. Bagian jalan meliputi strategi dan ide untuk mengejar kepentingan yang diinginkan tersebut. Bagian cara meliputi sumber daya-sumber daya yang tersedia bagi negara yang bersangkutan. Kebijakan luar negeri dengan demikian merupakan tindakan yang mewakilkan pertemuan antara politik domestik dan internasional. Oleh karena itu, kebijakan luar negeri dipengaruhi oleh dua faktor utama, yaitu faktor eksternal atau internasional dan faktor internal atau domestik.

Lingkungan internasional memainkan peran penting dalam membentuk kebijakan luar negeri setiap negara. faktor-faktor eksternal utama yang menentukan kebijakan luar negeri suatu negara, di antaranya (AS, 2008: 3) sistem internasional atau struktur kekuatan yang berkaitan dengan kekuatan relatif yang dimiliki suatu negara di dalam sistem internasional. Dunia secara terus-menerus mengalami perubahan. Peristiwa-peristiwa baru membawa perubahan yang signifikan 
dalam struktur kekuatan dan berdampak pada kebijakan luar negeri dari banyak negara.

Hukum internasional berkaitan dengan persetujuan dan perjanjian antar negara dan mengatur kebijakan luar negeri suatu negara serta memiliki fungsi mengikat dalam kebijakan luar negeri karena menyediakan kerangka kerja hukum pedoman interaksi antar negara. Organisasi internasional dianggap sebagai aktor yang aktif dalam bidang hubungan internasional karena mereka memfasilitasi interaksi antar negara di tingkat global. Kebijakan luar negeri suatu negara dengan demikian dipengaruhi oleh keanggotaannya dalam organisasi internasional, regional dan sub-regional karena mereka menyerahkan sebagian kedaulatannya kepada organisasi-organisasi tersebut.

Aliansi merupakan sebuah strategi yang digunakan suatu negara dalam pembentukan dan pelaksanaan kebijakan luar negeri mereka, terutama dalam kebijakan keamanan. Aliansi membentuk kebijakan luar negeri karena anggotanya harus merespon permintaan sekutu mereka dan menghindari pembentukan kebijakan atau bertindak yang merugikan mitra aliansinya. Strategi militer/arm race berkaitan dengan pertahanan dan pembangunan kapabilitas militer yang kompetitif antar dua negara atau blok negara. Dalam mencapai tujuan kebijakan luar negeri, negara mengadopsi beragam strategi, salah satunya strategi militer.

Sementara itu, faktor-faktor internal (AS, 2008: 5) yang menentukan kebijakan luar negeri suatu negara, di antaranya budaya dan sejarah yang berkaitan dengan nilai-nilai dan keyakinan tradisionalnya. Pengalaman historis, seperti budaya dan tradisi suatu negara berpengaruh pada kebijakan luar negerinya. Geografi, ukuran dan populasi juga sangat mempengaruhi implementasi dari kebijakan luar negerinya.

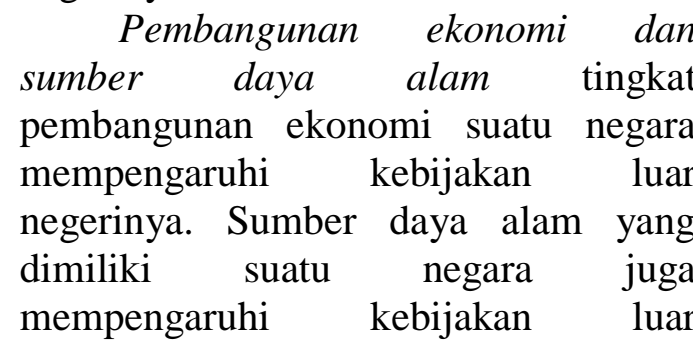
negerinya, seperti mineral, gas, minyak bumi atau minyak mentah, dan air. Negara-negara dengan sumber daya yang melimpah, walaupun berukuran kecil, memiliki peran penting dalam politik internasional. Kemampuan militer berkaitan dengan kapabilitas suatu negara untuk membela perbatasannya dari serangan senjata sehingga memainkan peran penting dalam pembuatan kebijakan internal maupun eksternalnya. Kemampuan militer yang semakin meningkat dapat mengubah kebijakan luar negerinya, dari penuh damai menjadi agresif. Di sisi lain, negara dengan kemampuan militer yang rendah cenderung lebih fokus pada pencapaian kebijakannya dan cenderung bergantung pada pencarian sekutu yang memiliki kemampuan lebih baik atau organisasi internasional untuk berlindung.

Sistem politik berkaitan dengan bentuk penerintahan. Di bawah bentuk pemerintahan yang otoriter atau totalitarian, pengambilan kebijakan luar negeri lebih cepat dan mudah karena kekuatan pembuatan kebijakan ada pada satu orang. Sementara itu, pada sistem demokratik, implementasi kebijakan luar negeri cenderung sulit dan lambat karena warga negara dapat mengekspresikan opini mereka dalam kebijakan domestik dan luar negeri negaranya. Sifat dan karakter pemimpin: menurut Rosenau (AS, 2018: 
7), keyakinan seorang pemimpin mengenai sifat arena internasional dan tujuan yang ingin dicapai, kekuatan dan kelemahan intelektualnya dalam menganalisis informasi dan membuat keputusan, latar belakangnya dan keterkaitannya dengan peran pemimpin, kebutuhan emosional dan lainnya dapat mempengaruhi perencanaan dan pelaksanaan kebijakan luar negeri. Pemimpin dikelompokkan ke dalam dua kategori, yaitu hawks, yaitu mereka yang menjalankan kebijakan luar negeri agresif berdasarkan kekuatan militer yang kuat, dan doves, yaitu pemimpin yang mendamaikan dan mencoba untuk menyelesaikan konflik internasional tanpa ancaman kekerasan.

Partai politik dan kelompok kepentingan memiliki kepentingan lebih dalam kebijakan luar negeri negara karena globalisasi. Kelompok kepentingan berada di antara pemerintah dan publik yang terikat dengan sistem pembuatan keputusan dengan beragam saluran komunikasi. Pers dan opini publik dapat berdampak pada kebijakan luar negeri dalam demokrasi, dengan menentukan siapa yang dipilih dan dengan mempengaruhi pemimpin setelah terpilih. Media juga dapat memainkan peran penting dalam mempengaruhi kebijakan dan keputusan yang dibuat pemimpin, termasuk media sosial yang semakin mudah diakses. Terakhir, ilmu pengetahuan dan teknologi penting untuk mengantisipasi dan menyelesaikan masalah serta mencapai tujuan kebijakan luar negeri. Rosenau (dalam AS, 2018: 8) menyebutkan bahwa kemajuan teknologi dapat mendorong kemampuan militer, ekonomi, status, dan peran suatu negara.

\section{Metode Penelitian}

Penelitian ini menggunakan pendekatan kualitatif, dengan jenis penelitian deskriptif. Pendekatan kualitatif digunakan karena disesuaikan dengan latar belakang masalah dalam memperoleh jawaban pertanyaan penelitian, yaitu faktor-faktor yang mempengaruhi kebijakan keterlibatan Indonesia dalam KSS periode 20042018. Penelitian ini merupakan penelitian deskriptif karena menghasilkan hasil penelitian yang sistematis dalam menggambarkan permasalahan penelitian, yaitu faktorfaktor eksternal dan internal yang mempengaruhi kebijakan keterlibatan Indonesia dalam KSS periode 20042018. Teknik pengumpulan data dalam penelitian ini akan dilakukan dengan teknik pengumpulan data kualitatif untuk mendapatkan data yang diperlukan dalam penelitian, antara lain data primer dan data sekunder. Data primer akan diperoleh melalui berbagai data resmi dari website resmi pemerintah Indonesia. Data sekunder akan diperoleh melalui studi kepustakaan dari sumber-sumber tertulis, seperti buku, website lainnya, jurnal online, dan data-data statistik.

\section{Hasil dan Diskusi}

Berdasarkan teori di atas dan data-data yang telah diperoleh, maka pada periode 2004 hingga tahun 2018 dapat digolongkan ke dalam dua masa pemerintahan Presiden Indonesia, yaitu Presiden Susilo Bambang Yudhoyono (SBY) dan Presiden Joko Widodo (Jokowi). SBY memerintah selama dua periode, yaitu pada tahun 2004-2009 dan 2009-2014, sedangkan Jokowi pada tahun 2014 hingga sekarang. 
Pada Masa Pemerintahan Presiden Susilo Bambang Yudhoyono (20042014)

Pada masa pemerintahan Presiden SBY, yaitu tahun 2004 hingga tahun 2014, faktor-faktor eksternal dari lingkungan internasional mempengaruhi kebijakan keterlibatan Indonesia dalam KSS. Pada masa itu, dalam sistem internasional, Indonesia merupakan negara yang menyandang status negara berpendapatan menengah ke bawah atau lower-middle income country tepatnya pada tahun 2008. Dengan gelar tersebut Indonesia menjadikan KSS sebagai salah satu upaya untuk berinteraksi dengan negara yang juga berkembang dengan semboyan one million friend zero enemy. Hubungan baik Indonesia dengan negara-negara berkembang yang telah ada sejak KAA, pada masa Presiden SBY dijadikan dasar untuk melanjutkan prioritas kerjasama teknis antar negara berkembang dibanding masa-masa pemerintahan era reformasi sebelumnya, walaupun KSS tidak menjadi prioritas dalam kebijakan luar negeri Indonesia pada masa itu. Presiden SBY lebih menonjolkan sisi million friend karena lebih antusias untuk mengajak negara-negara maju menghilangkan diskriminasi terhadap negara berkembang, dibanding prioritasnya sebagai negara selatan. Pergeseran kekuatan ekonomi dari Barat ke Timur karena banyak emerging power dari negara-negara berkembang, seperti Indonesia, membuat KSS semakin penting sebagai sarana interaksi Indonesia dengan negaranegara berkembang lainnya.

KSS sebagai suatu wadah bersama yang mencakup banyak negara di dalamnya tentu memiliki hukum internasional yang berlaku bagi seluruh anggotanya. Hukum ini diberlakukan agar setiap negara dalam KSS dapat saling berinteraksi dan beraktivitas dengan saling menguntungkan. Dalam KSS terdapat kesepakatan akan adanya pertukaran pengetahuan, teknologi, bencana dan perbaikan lewat programprogram proyek, dan inisiatif untuk membantu menyelesaikan masalah negara-negara berkembang. Setiap negara yang menyetujui kesepakatan tersebut harus mengikuti peraturan yang disetujui bersama.

KSS merupakan suatu organisasi internasional yang memainkan peran penting dalam sistem internasional karena mencakup banyak negara-negara berkembang di dunia. KSS merupakan aktof yang aktif dalam memfasilitasi interaksi antar negara-negara berkembang di tingkat global. Keanggotaan Indonesia dalam KSS mempengaruhi kebijakannya dalam berinteraksi dengan negara-negara berkembang. KSS menjadi salah satu prioritas nasional Indonesia dalam RPJMN Indonesia tahun 20010-2014. Berdasarkan komitmen Indonesia tersebut, keanggotaan Indonesia dalam KSS membuat Indonesia membangun Grand Design dan Blue Print dari KSS untuk mengidentifikasi kebijakan, strategi, dan implementasi dari KSS ke depannya. Kesadaran dari negaranegara berkembang anggota KSS akan hubungan yang saling membutuhkan membuat negara-negara tersebut berkomitmen untuk terus bekerjasama dalam KSS sampai sekarang. SBY juga membuat persetujuan-persetujuan internasional berkaitan dengan KSS yang bertujuan untuk memperkuat komitmen negara-negara berkembang dalam KSS (Center for East Asian Cooperation Studies (CEACos), 2010: 64-67). Beberapa perjanjian internasional terkait mekanisme KSS yang ada pada saat pemerintahan SBY antara lain Deklarasi Paris 2005, Accra 
Agenda for Action 2008, Doha Conference, Review on Financing for Development 2008, dan Konferensi Perserikatan Bangsa-Bangsa (PBB) mengenai KSS di Nairobi, Kenya di tahun 2009 yang menghasilkan Nirobi Outcome Document. Kesepakatankesepakatan tersebut pada dasarnya adalah untuk meneguhkan komitmen negara berkembang dalam KSS (Center for East Asian Cooperation Studies (CEACos), 2010: 72).

Kesadaran tersebut juga dijadikan dasar untuk membangun hubungan yang baik antar setiap negara di dalam KSS. Hubungan antara negara-negara selatan terus menguat dan menjadi perhatian global. Hubungan tersebut lebih kepada hubungan ekonomi dan solidaritas karena adanya pengalaman yang sama dan kondisi yang sama dari negaranegara selatan-selatan. Aliansi dalam hal keamanan kurang difokuskan dalam KSS. Walaupun demikian, setiap negara dalam KSS juga harus saling menghormati kepentingan negara lainnya, saling membantu menuju kemajuan bersama, kemitraan yang sejajar, dan tidak saling merugikan satu sama lain. Indonesia mengarahkan kebijakannya pada formulasi kemitraan yang setara dan berkelanjutan antara negara berkembang dan negara maju atau institusi internasional lainnya lewat South-South Technical Cooperation (SSTC).

Arm race tidak menjadi perhatian utama dalam KSS karena dalam kerjasama ini setiap negara selatan berkomitmen untuk saling membantu menuju kemajuan bersama dan membangun hubungan baik dengan kemitraan yang sejajar, terutama dalam bidang ekonomi. Kepentingan Indonesia terutama terhadap negara-negara Pasifik sebelumnya adalah untuk membendung kekuatan-kekuatan superpower, namun saat ini berkembang menjadi berfokus kepada penanganan masalah-masalah non-militer yang mengancam kedaulatan dan stabilitas kawasan. Indonesia menitikberatkan pada pendekatan menggunakan kekuatan lunak atau soft power.

Berdasarkan

faktor-faktor internal, keterlibatan Indonesia dalam KSS sangat dipengaruhi oleh budaya dan sejarah Indonesia. Pada masa pemerintahan Presiden SBY, diselenggarakan Asian-African Summit, yaitu peringatan ulang tahun ke-50 KAA pada bulan April tanggal 22 hingga 24 tahun 2005 di Jakarta dan Bandung (Assie-Lumumba, 2015: 2). Pada pemimpin negara-negara Asia dan Afrika dalam kesempatan ini bertujuan untuk menghidupkan kembali semangat KAA Bandung dan memperbaharui komitmen untuk mencapai tujuannya lewat kerjasama yang baru antara Asia dan Afrika. Dalam menyelesaikan masalah negara-negara berkembang, Indonesia terus melanjutkan peninggalan KAA dengan terus melanjutkan hubungan baik dengan negara-negara berkembang dalam KSS. Budaya Indonesia yang beragam tetap menyatu dalam hal membantu negaranegara yang sama-sama berkembang dengan pengalaman penjajahan dan masalah-masalah yang hampir serupa. Indonesia merupakan negara dengan ukuran besar yang secara geografis terletak strategis di antara dua benua dan dua samudera besar yang merupakan jalur perdagangan dunia. Populasi Indonesia yang mencapai 240 juta jiwa di tahun 2010 merupakan populasi terbesar di Asia Tenggara. Sumber daya Indonesia yang melimpah menjadikan Indonesia negara penting di dunia. Pada masa Presiden SBY, Indonesia merupakan penghasil minyak kelapa sawit terbesar di dunia tahun 
2006 dengan produksi 16,08 juta ton (Ermawati dan Saptia, 2013). Minyak kelapa sawit merupakan komoditas yang penting bagi dunia karena dapat dijadikan berbagai macam benda yang dibutuhkan sehari-hari, seperti sabun, minyak goreng, produk kecantikan, dan lain-lain.

Pada masa pemerintahan SBY, pertumbuhan ekonomi Indonesia relatif stabil, hanya mengalami kenaikan dan penurunan yang kurang signifikan. Pada tahun 2008 menyandang status negara berpendapatan menengah ke bawah atau lower-middle income country. Indonesia juga merupakan ekonomi terbesar di Kawasan Asia Tenggara. Analis ekonomi memasukkan Indonesia sebagai emerging economy karena keberhasilannya dalam pertumbuhan ekonomi yang sangat cepat, bahkan angka pertumbuhannya melebihi negara-negara maju. Pada tahun 2011, Indonesia merupakan ekonomi terbesar ke-10 dunia dengan share Gross Domestic Bruto (GDP) Indonesia terhadap total GDP dunia mencapai 2,3\%, padahal tahun 2005 Indonesia belum menempati posisi dua belas besar (The Jakarta Post, 2014). Sebagai negara yang masuk kategori negara berpendapatan menengah, Indonesia memiliki tanggung jawab untuk membantu negara-negara berkembang lain, yaitu salah satunya dalam KSS. Selain sebagai penerima bantuan (beneficiary countries) dari negaranegara lain di dunia, pada saat yang sama Indonesia memikul tanggung jawab untuk memainkan peran sebagai penyedia bantuan pembangunan (provider). Sebagai salah satu anggota G20, Indonesia memberikan perhatian besar terhadap pembangunan negaranegara berkembang. Untuk meningkatkan komitmennya dalam KSS, Indonesia berkontribusi sebesar
USD 1,5 juta kepada South-South Exchange Facility dari World Bank. Anggaran yang dialokasikan Indonesia untuk KSS pada tahun 2014 sebesar USD 1,2 juta pada tahun 2014 (Alta dan Pamasiwi, 2018: 3).

Dari aspek kemampuan militer, Indonesia tidak menitikberatkan pada kemiliteran atau kekerasan dalam KSS. Kemandirian Indonesia dalam KSS ditunjukkan lebih kepada soft power yang dimilikinya. Sebagai salah satu anggota dari G20, Indonesia diberikan privilege untuk lebih meningkatkan hubungannya dengan negara-negara berkembang dan KSS, sehingga upaya Indonesia dapat lebih diakui dalam kerjasama pembangunan internasional dan dapat memainkan peran lebih besar untuk meningkatkan keterlibatannya kepada negara-negara berkembang. Salah satu bentuk upaya Indonesia dalam memainkan peran kepemimpinan dalam KSS terlihat saat Indonesia menyelenggarakan forum tingkat tinggi mengenai pertukaran pengetahuan yang melibatkan lebih dari 300 pembuat kebijakan dan praktisi dari 46 negara pada tahun 2012 (Alta dan Pamasiwi, 2018: 3).

Sistem politik Indonesia dalam konteks KSS, pada tataran instansi pelaksana, tahun 2005 Kementerian Luar Negeri menjalani proses restrukturisasi. Dilakukan pembentukan direktorat baru di dalamnya, yaitu Direktorat Kerjasama Teknik (KST). Direktorat tersebut bertujuan untuk meningkatkan peran aktif Indonesia dalam kerjasama dengan negara-negara berkembang. Selain itu, dalam perumusan kebijakan Indonesia yang berkaitan dengan KSS, Direktorat Sosial Budaya dan Organisasi Internasional Negara Berkembang juga diarahkan menjadi focal point (Center for East Asian Cooperation Studies 
(CEACos), 2010: 71). Indonesia merupakan negara yang demokratis dengan sistem pemeritahan presidensial, yaitu Presiden SBY pada periode 20042014.

Sifat dan karakter Presiden SBY, walaupun memiliki latar belakang militer, namun termasuk ke dalam kategori doves, yaitu pemimpin yang mendamaikan dan mencoba menyelesaikan konflik internasional tanpa ancaman kekerasan. Namun demikian, SBY tergolong pemimpin yang tegas dan berani karena melahirkan sebuah konsep politik luar negeri yang disebutnya sebagai "navigating on turbulent ocean" atau mendayung di samudera yang bergejolak. Presiden SBY sebagai Presiden Indonesia menghadapi tantangan yang lebih kompleks di ranah internasional. Walaupun kerjasama teknis di antara negara-neara berkembang mendapatkan tempat yang lebih baik dibandingkan pada pemerintahan era reformasi sebelumnya, SBY juga mengambil langkah kerjasama dengan negaranegara maju untuk mencapai tujuantujuan nasionalnya. Pada masa itu juga Indonesia akan bekerjasama dengan siapapun yang memiliki niat dan tujuan sama, terutama untuk membangun tatanan dunia yang damai, adil, demokratis, dan sejahtera.

Presiden SBY juga merupakan tokoh dari partai politik, yaitu Partai Demokrat. Oleh karena itu, tindakantindakan Presiden SBY dilakukan berdasarkan persetujuan dengan partai pengusung dan koalisinya. Hal tersebut dikarenakan, Indonesia merupakan negara yang demokratis dengan banyak partai politik yang berperan penting dalam membentuk demokrasi keterwakilan di Indonesia. Partai politik dijadikan salah satu sarana yang digunakan masyarakat Indonesia untuk menyalurkan suaranya ke dalam perumusan kebijakan di Indonesia.

Menurut opini publik, dalam hal ini pandangan kelompok swasta di Indonesia, pada masa pemerintahan Presiden SBY, KSS yang dilakukan pemerintah dinilai lebih menitikberatkan pada persoalan politik yang melibatkan kegiatan pemerintah, daripada penanganan masalah ekonomi. Kerjasama ini lebih bersifat politik sehingga hanya verfokus pada kegiatan pemerintah tanpa banyak melibatkan sektor swasta. Hal ini membuat jalinan person to person atau company to company antar negara selatan, khususnya Indonesia dengan negaranegara di Afrika dan Amerika Latin sangat terbatas (Falahi, 2015: 106). Namun demikian, sektor privat dan organisasi non-pemerintahan juga dilibatkan menjadi agen-agen pelaksanaan dari National Coordination Team on South-South Cooperation (NCT-SSC) (Alta dan Pamasiwi, 2018: 4). NCT-SSC dibuat pada tahun 2010 untuk menangani dan menyelesaikan masalah multiple stakeholders dan struktur institusional KSS yang kompleks di Indonesia.

Dalam menjalankan kebijakankebijakannya dalam KSS, Indonesia juga memanfaatkan kemajuan ilmu pengetahuan dan teknologi yang dimilikinya. Dengan sumber daya yang dimilikinya, Indonesia banyak memberikan bantuan ke negara-negara selatan dalam KSS. Pada periode tahun 2003 hingga tahun 2007, Indonesia telah menyelenggarakan program pelatihan untuk negara berkembang di berbagai bidang. Peserta program tersebut mencapai 727 orang dari 51 negara di Asia, Pasifik, dan Afrika. Jumlah tenaga ahli yang dikirim dari Indonesia ke negara-negara lain dalam 
program tersebut selama periode tahun 1997 hingga tahun 2007 mencapai 50 orang. Para tenaga ahli tersebut dikirim ke Papua Nugini, Madagaskar, Nepal, Tanzania, Kamboja, Filipina, dan Thailand. Selain dalam bentuk pelatihan dan tenaga ahli, Indonesia juga memberikan beasiswa kepada 100 orang dari Asia, Pasifik, dan Australia. Para peserta beasiswa tersebut mempelajari kebudayaan Indonesia di beberapa tempat, yaitu Saung Angklung Mang Udjo di Bandung dan Padepokan Tari Bagong Kusudiardjo di Yogyakarta. Para peserta beasiswa tersebut mempelajari seni dan budaya Indonesia selama tiga bulan (Center for East Asian Cooperation Studies (CEACos), 2010: 72). Selain untuk mempromosikan seni dan budaya Indonesia, kegiatan ini juga ditujukan untuk mempromosikan soft power yang dimiliki Indonesia terhadap negaranegara Pasifik.

Pembagian pengetahuan dari Indonesia dilakukan kepada sesama negara berkembang untuk saling berbagi informasi, pengetahuan, dan teknologi yang berguna bagi pembangunan ekonomi negara-negara penerima. Antara tahun 2010 hingga tahun 2012, Indonesia telah menyediakan lebih dari 700 aktivitas di dalam KSS yang melibatkan sekitar 3.800 peserta dari Asia, Pasifik, Afrika, Timur Tengah, dan Amerika Latin. Dari tahun 2014 hingga tahun 2016, Indonesia telah menyelenggarakan 134 program yang dihadiri oleh 2.222 peserta dari Asia, Pasifik, Timur Tengah, Amerika Latin, dan Afrika dengan total anggaran USD 23,48 juta (Alta dan Pamasiwi, 2018: 3).

\section{Pada Masa Pemerintahan Joko Widodo (2014-sekarang)}

Setelah masa pemerintahan Presiden SBY, Presiden Joko Widodo (Jokowi) menjadi kepala negara dan kepala pemerintahan Indonesia tahun 2014 hingga sekarang. Perubahan pemimpin ini tentu juga berpengaruh pada perubahan kebijakan luar negeri Indonesia terkait keterlibatannya dalam KSS. Perubahan lingkungan internasional dan domestik pada masa pemerintahan Presiden Joko Widodo akan mempengaruhi kebijakan Indonesia. Faktor eksternal pertama adalah sistem internasional yang dinamis. Di dalam Nawacita, yaitu sembilan program perubahan untuk Indonesia, terdapat misi untuk meningkatkan peran Indonesia secara regional dan global sebagai negara middle power. Dalam Nawacita juga dijelaskan pentingnya meningkatkan komitmen dalam KSS, khususnya pada agenda keamanan, perlindungan warganegara dan program urusan luar negeri (Alta dan Pamasiwi, 2018: 3). Di dalam RPJMN Indonesia tahun 2015 hingga tahun 2019 juga disebutkan bahwa pusat ekonomi dunia ke depan diperkirakan akan bergeser dari kawasan Eropa-Amerika ke kawasan Asia-Pasifik. Pertumbuhan ekonomi dari negara-negara berkembang yang tinggi akan mendorong negara berkembang menjadi motor penggerak pertumbuhan ekonomi dunia. (Kementerian Perencanaan Pembangunan Nasional/Badan Perencanaan Pembangunan Nasional, 2014). Dengan demikian, pemerintahan Jokowi telah mengantisipasi pergeseran kekuatan dunia yang semakin terlihat dengan beradaptasi dan terus melakukan perbaikan agar tidak tertinggal, salah satunya dengan semakin meningkatkan komitmen dalam KSS. Hal tersebut 
dibuktikan dengan menguatnya hubungan antar negara-negara selatan.

$$
\text { Dalam aspek hukum }
$$

internasional, KSS mencakup negaranegara berkembang yang berkumpul untuk membagi pengetahuan, keahlian, dan inisiatif kesuksesan pada area-area tertentu, yaitu pembangunan pertanian, hak asasi manusia, urbanisasi, kesehatan, perubahan iklim, dan lainlain. Dalam melakukan aktivitasaktivitas tersebut, setiap negara harus mematuhi dan menghormati peraturan atau pedoman yang mengaturnya. Hal tersebut dilakukan untuk tetap memelihara iklim kerjasama yang kondusif dan setiap kepentingan negara yang dibawa ke dalam KSS dapat terpenuhi.

Dalam hal organisasi internasional, meningkatnya kesadaran akan saling ketergantungan bagi negaranegara selatan serta pentingnya bantuan dari negara maju, maka pada peringatan 60 tahun KAA tahun 2015 dihasilkan Kerjasama Selatan Selatan dan Triangular (Kementerian Komunikasi dan Informatika Republik Indonesia, 2015). Kerjasama tersebut merupakan manifestasi dari rasa solidaritas di antara negara-negara berkembang. Selain itu, pada tahun 2017 diselenggarakan Global South-South Development Expo di Turki yang dihadiri oleh 800 peserta dari 120 negara, pejabat senior PBB, Menterimenteri, direktur institusi pembangunan nasional dan perwakilan dari civil society untuk membagi solusi inovatif dan mendorong inisiatif konkrit dari negara-negara selatan untuk mencapai agenda 2030 dan 17 Sustainable Development Goals (SDGs) (Kamal, 2017).

Berdasarkan konteks aliansi, pemanfaatan KSS bagi kepentingan politik luar negeri Indonesia berhasil memperluas jaringan diplomasi Indonesia di dunia Internasional. Indonesia telah banyak membangun hubungan baik dengan berbagai negara, terutama negara berkembang dan negara maju. Kebijakan luar negeri KSS memainkan peran penting dalam menghadapi berbagai ancaman separatism, terutama guna mencegah adanya internasionalisasi isu-isu separatism di dalam negeri serta mengupayakan dukungan internasional terhadap integritas wilayah Indonesia. Dalam masa pemerintahan Presiden Jokowi, KSS juga tidak ditekankan pada arm race. KSS lebih menekankan pada dua sasaran strategis, yaitu meningkatkan kualitas pembangunan masing-masing negara selatan dan meningkatkan koordinasi sesame anggota kelompok selatan. KSS bukan merupakan ajang perlombaan dalam hal kemiliteran. KSS sepenuhnya dibangun untuk memperkuat solidaritas, kedamaian, dan kemakmuran dunia.

Sementara itu, faktor-faktor internal yang menentukan kebijakan Indonesia dalam KSS, di antaranya budaya dan sejarah. Pentingnya sejarah dari KSS yang berkaitan dengan KAA dibuktikan lagi dengan menjadi penyelenggara peringatan ulang tahun KAA yang ke-60 di Jakarta dan Bandung pada tanggal 19 sampai 24 April tahun 2015. Acara tersebut dihadiri oleh 34 kepala negara dan 77 perwakilan dari organisasi internasional (Alta dan Pamasiwi, 2018: 3). Banyaknya tamu yang hadir membuktikan bahwa hubungan Indonesia dengan negara-negara KSS semakin menguat dan tetap menghormati sejarah yang menyatukan mereka. Hal ini juga menunjukkan pentingkan tatanan ekonomi internasional baru yang terbuka bagi emerging powers. Secara geografis, 
kondisi Indonesia tidak berubah. Indonesia masih merupakan negara dengan ukuran besar yang terletak strategis di antara dua benua dan dua samudera besar yang merupakan jalur perdagangan dunia. Populasi Indonesia yang mencapai 240 juta jiwa pada sensus penduduk tahun 2010 merupakan populasi terbesar di Asia Tenggara. Dalam hal sumber daya alam, produksi minyak sawit Indonesia pada tahun 2016 telah menjadi yang terbesar di dunia, yaitu sebesar 34,52 juta ton (Varqa, 2017).

Dalam hal pembangunan ekonomi, pertumbuhan anggaran Indonesia untuk KSS meningkat dari USD 1,2 juta pada tahun 2014 menjadi USD 1,5 juta pada tahun 2015. Alokasi anggaran untuk tahun 2016 sepuluh kali lipat dari tahun 2015, yaitu sebesar lebih dari USD 15 juta (Alta dan Pamasiwi, 2018: 3). Hal tersebut menunjukkan bahwa komitmen Indonesia dalam KSS pada masa pemerintahan Presiden Jokowi ini semakin meningkat. Sejak tahun 1999 hingga tahun 2016, Indonesia telah menyalurkan anggaran USD 57,4 juta. Anggaran tersebut berasal dari Anggaran Pendapatan dan Belanja Negara (APBN), pihak ketiga (triangular) seperti negara maju atau mitra pembangunan, dan sumber daya resmi lainnya. Anggaran dari banyak program masih terbagi dan berasal dari kementerian-kementerian pelaksana. Pada masa pemerintahan Presiden Jokowi, Indonesia memainkan peran sebagai penyedia bantuan pembangunan (provider) dalam KSS. Sumber daya alam Indonesia melimpah, khususnya kelapa sawit. Produksi kelapa sawit Indonesia naik dari 29,28 juta ton pada tahun 2014 menjadi 31,07 juta ton pada tahun 2015. Pada tahun 2016, Indonesia mampu menghasilkan 34,52 juta ton atau 58\% dari total produksi minyak sawit dunia yang berhasil melampaui Malaysia sebesar 29\%, Thailand sebesar $4 \%$, Colombia sebesar 2\%, dan gabungan negara lainnya sebesar 7\% (Varqa, 2017). Sejak tahun 2014 hingga 2017, produksi minyak sawit Indonesia terus bertambah setiap tahunnya.

Dari aspek kemampuan militer, pada masa pemerintahan Presiden Jokowi, Indonesia juga tidak menitikberatkan pada kemiliteran atau kekerasan dalam KSS. Kemandirian Indonesia dalam KSS masih berfokus pada soft power yang dimilikinya. Indonesia lebih menekankan pada penguatan hubungan dengan negaranegara berkembang, sehingga upaya Indonesia dapat lebih diakui dalam kerjasama pembangunan internasional dan dapat memainkan peran lebih besar untuk meningkatkan keterlibatannya dalam sistem internasional.

Dalam konteks sistem politik, Indonesia pada masa pemerintahan Presiden Jokowi pada periode 2014 sampai sekarang masih merupakan negara yang demokratis dengan sistem pemeritahan presidensial. Berkaitan dengan KSS, NCT-SSC yang dibuat pada tahun 2010 untuk menangani dan menyelesaikan masalah multiple stakeholders dan struktur institusional KSS yang kompleks di Indonesia masih beroperasi pada masa pemerintahan Presiden Jokowi. Bahkan, KSS lewat NCT Indonesia telah mencapai kemajuan pada sistem koordinasinya. NCT dapat mempublikasikan laporan tahunan, pengumpulan dan pemrosesan data dari permintaan negara mitra, data pusat keunggulan, dan anggaran. Selain itu NCT juga memulai membangun sistem pengembangan yang mencakup Standard Operating Procedure (SOP), informasi dan teknologi, strategi komunikasi, strategi branding, daftar 
negara yang diprioritaskan, dann perencanaan serta penganggaran. NCT juga dapat menyelenggarakan beberapa proyek dalam berbagai sektor seperti pertanian, inseminasi buatan, desentralisasi fiskal, dan kewiraswastaan (Alta dan Pamasiwi, 2018: 3).

Namun demikian, NCT-SSC menghadapi banyak tantangan karena bukan merupakan satu institusi yang dikhususkan menangani KSS Indonesia. Walaupun memperoleh banyak pencapaian dari program donornya selama tahun 2010 hingga 2016, implementasi KSS Indonesia secara umum terbagi dan jauh dari keuntungan maksimal. Masalah tersebut berhasil ditangani pada tahun 2016, di mana KSS Indonesia mengalami kemajuan. Pada pertengahan tahun 2016, proses menuju pembentukan institusi khusus KSS telah mengalami kemajuan. Pada akhir tahun 2017, diskusi mengenai pembentukan instansi tersebut diangkat lagi dalam keputusan presiden, namun sampai sekarang masih belum jelas. Diskusi pada bulan Mei tahun 2016 yang dilaksanakan oleh Kementerian Luar Negeri dan tiga kementerian kunci lainnya tidak mencapai hasil yang diharapkan (Alta dan Pamasiwi, 2018: $5)$.

Sifat dan karakter Presiden Jokowi, dengan latar belakang yang bukan dari militer, termasuk juga ke dalam kategori doves, yaitu pemimpin yang mendamaikan dan mencoba menyelesaikan konflik internasional tanpa ancaman kekerasan. Namun demikian, Presiden Jokowi juga merupakan pemimpin yang memiliki visi yang jauh ke depan. Presiden Jokowi memasukkan pentingnya meningkatkan hubungan antar negara selatan ke dalam Nawacita atau salah satu dari sembilan prioritas pemerintahannya. Dalam pemerintahan Presiden Jokowi, komitmen Indonesia dalam KSS lebih ditingkatkan dalam rangka adaptasi lebih lanjut ke dalam pergeseran kekuatan dunia. Jokowi dengan visinya ingin membawa Indonesia dan negara-negara berkembang lainnya untuk maju dan lebih memperbaiki perekonomiannya terutama mencapai janji utama dari agenda 2030, yaitu "leave no-one behind".

Presiden Jokowi juga merupakan tokoh dari partai politik, yaitu Partai Demokrasi Indonesia Perjuangan (PDIP). Tindakan-tindakan Presiden Jokowi tidak luput dari suara partai. Hal tersebut dikarenakan, Indonesia merupakan negara yang demokratis dengan banyak partai politik yang berperan penting dalam membentuk demokrasi keterwakilan di Indonesia. Partai politik akan tetap dijadikan salah satu sarana yang digunakan masyarakat Indonesia untuk menyalurkan suaranya ke dalam perumusan kebijakan di Indonesia. Sektor privat dan organisasi non-pemerintahan masih tetap dilibatkan menjadi agen-agen pelaksanaan dari NCT-SSC. Hal tersebut dikarenakan NCT-SSC memang dibuat pada tahun 2010 untuk menangani dan menyelesaikan masalah multiple stakeholders dan struktur institusional KSS yang kompleks di Indonesia. Selain itu, keterbukaan jalan bagi kontribusi masyarakat untuk mendorong kesuksesan KSS itu sendiri dengan cara menyalurkan keahlian dan pengetahuannya telah disediakan.

Dalam bidang ilmu pengetahuan dan teknologi, Indonesia masih terus mengadakan pembagian pengetahuan yang dilakukan kepada sesama negara berkembang untuk saling berbagi informasi, pengetahuan, dan teknologi yang berguna bagi pembangunan 
ekonomi negara-negara penerima. Aktivitas-aktivitas di dalam KSS tersebut tetap melibatkan peserta dari Asia, Pasifik, Afrika, Timur Tengah, dan Amerika Latin (Alta dan Pamasiwi, 2018: 3). Indonesia juga telah menyelenggarakan banyak program pengembangan kapasitas (capacity building) dalam bentuk pelatihan, workshops, pengiriman tenaga ahli, magang, dan beasiswa. Sejak tahun 1999 hingga tahun 2016, Indonesia telah melaksanakan 783 program dan aktivitas, dengan 5.091 peserta (Alta dan Pamasiwi, 2018: 3).

\section{Kesimpulan}

Faktor-faktor yang mempengaruhi kebijakan keterlibatan Indonesia dalam KSS pada periode 2004-2018 dapat dilihat dari dua masa pemerintahan Presiden Indonesia, yaitu Presiden SBY periode 2004-2014 (dua periode) dan Presiden Jokowi periode 2014 hingga sekarang. Perbedaan kondisi dan situasi baik dari eksternal dan internal Indonesia terkait faktor-faktor yang mempengaruhi kebijakan keterlibatan Indonesia dalam KSS pada periode 2004-2018, membuat kebijakan yang diambil kedua Presiden pada masa itu juga berbeda. Faktor-faktor eksternal seperti sistem internasional, hukum internasional, organisasi internasional, aliansi, dan arm race, pada masa pemerintahan Presiden SBY membuat kebijakan yang diambil lebih menekankan pada hubungan baik dengan siapa saja, terutama dengan negara maju karena KSS bukan prioritas utama. Faktor-faktor internal seperti budaya dan sejarah, kondisi geografis, pertumbuhan ekonomi, kemampuan militer, sifat dan karakter pemimpin, partai politik, opini publik, serta ilmu pengetahun dan teknologi mempengaruhi kebijakan Presiden SBY menekankan pada peningkatan status Indonesia secara merata di hampir setiap bidang, seperti dalam pengalokasian anggaran KSS, penyelenggaraan forum tingkat tinggi, restrukturisasi, peningkatan frekuensi kerjasama, dan peningkatan soft power Indonesia. Sementara kebijakan Presiden Jokowi terkait kondisi faktorfaktor eksternalnya dan KSS, tergolong lebih menekankan pada hubungan dengan negara-negara berkembang karena termasuk ke dalam salah satu prioritas utama pemerintahannya dalam menghadapi pergeseran kekuatan dunia. Faktor-faktor internal pada masa Presiden Jokowi membuat kebijakannya lebih mengarah pada pemanfaatan sumber daya yang dimiliki Indonesia, seperti peningkatan alokasi anggaran KSS, kemajuan pada NCT-SSC dan upaya pembentukan instansi tunggal KSS, serta keterbukaan akses masyarakat untuk menyalurkan kemampuan dan keahliannya dalam KSS.

\section{Saran}

Kesadaran akan pentingnya KSS harus lebih ditingkatkan lagi bagi Indonesia maupun negara-negara mitranya agar pelaksanaan KSS ini dapat bertahan hingga jangka panjang. Selain itu, proses pelaksanaan KSS perlu ditata agar kemajuan atau kemunduran yang dialami dapat diamati lebih jelas sehingga dapat diambil tindakan perbaikan dengan cepat dan tepat agar dapat mencapai tujuannya. Selain itu, keterlibatan sektor swasta, organisasi non-pemerintah, dan masyarakat perlu ditingkatkan dalam program KSS. Keterbukaan akses dalam memberikan kontribusi perlu dibuka lebih luas dan diinformasikan lebih luas agar masyarakat dapat mengetahui cara dan persyaratan yang berlaku. Hal ini dapat 
membantu Indonesia dalam mengembangkan diri dan meningkatkan komitmennya dalam KSS.

\section{DAFTAR PUSTAKA}

Adnan, Mubeen (2014) "Foreign Policy and Domestic Constraints: A Conceptual Account", South Asian Studies, A Research Journal of South Asian Studies, Vol. 29, No. 2, July-December 2014, pp. 657-675.

Alta, Aditya \& Pamasiwi, Rhapsagita Malist (2018) "Indonesian SouthSouth Cooperation: Stepping Up the Institution and Strategy for Indonesia's Development Assistance", LPEM-FEBUI Working Paper - 017, February 2018, pp. 1-10.

Arsip Nasional Republik Indonesia (ANRI) \& UNESCO (2015) "Arsip Konferensi Asia Afrika dan Gerakan Non-Blok sebagai UNESCO Memory of the World", https://unesdoc.unesco.org/ark:/48 223/pf0000235221 diakses pada tanggal 2 Mei 2019, pukul 21:06 WIB.

AS, Bojang (2018) "The Study of Foreign Policy in International Relations", Journal of Political Sciences \& public Affairs 2018, 6:4-Oktober 2018, pp. 1-9.

Asia Corporate News Network (2015) "Indonesia Enhances Role in South-South Cooperation (19 Maret 2015)", https://search.proquest.com/docvi ew/1664459079?accountid=17242 diakses pada tanggal 10 Februari 2017, pukul 9:44 WIB.

Asia News Monitor (2016) "Indonesia: Indonesia, Africa Intensify SouthSouth Cooperation", http://search.proquest.com/docvie $\underline{\mathrm{w} / 1792575226 \text { ?accountid=17242 }}$ diakses pada tanggal 17 Oktober 2016, pukul 10:21 WIB.

Assie-Lumumba, N'Dri Therese (2015) "Behind and Beyond Bandung: Historical and Forward-Looking Reflections on South-South Cooperation", Bandung: Journal of the Global South (2015) 2:11, pp. 1-10.

Center for East Asian Cooperation Studies (CEACos) (2010) "Policy Direction on Indonesia's SouthSouth Cooperation. Aid for Development Effectiveness Secretariat", Japan International Cooperation Agency. pp. 1-205.

Ermawati, Tuti dan Saptia, Yeni (2013) "Kinerja Ekspor Minyak Kelapa Sawit Indonesia", http://www.kemendag.go.id/files/ pdf/2014/04/08/-1396953386.pdf diakses pada tanggal 22 Januari 2019, pukul 19:26 WIB.

Falahi, Ziyad (2015) "Prospek Diplomasi Indonesia adlam Kerjasama Selatan-Selatan: Refleksi Teoritis Kajian Kapitalisme Konsumen di Era Susilo Bambang Yudhoyono", Jurnal Politik Internasional Vol. 17, No. 1, Mei 2015, pp. 96-109.

Fardah (2016) "Indonesia Strengthens Ties with South Pacific Nations", www.antaranews.com/en/news/10 4056/indonesia-strengthens-tieswith-south-pacific-nations diakses pada tanggal 12 Oktober 2016, pukul 13:31 WIB.

Faridz, Devianti (2015) "Indonesia to Send Humanitarian Aid to Nepal", www.channelnewsasia.com/news/ asiapacific/indonesia-tosend/1810368.html diakses pada tanggal 12 Oktober 2016, pukul 14:21 WIB.

Ishida, Yoko, et. al (2011) "The Study on Current State and Prospect of 
South-South and Triangular Cooperation by ASEAN Emerging Donors", www.mofa.go.jp/mofaj/gaiko/oda/ files/000073030.pdf diakses pada tanggal 12 Oktober 2016, pukul 13:09 WIB.

Kamal, Baher (2017) "South-South Cooperation Key to a New Multilateralism", https://search.proquest.com/docvi ew/1972151417/91EDC9AD69C A4840PQ/20?accountid $=17242$ diakses pad atanggal 11 Mei 2019, pukul 11:25 WIB.

Kementerian Komunikasi dan Informatika Republik Indonesia (2015) "KAA: Kerjasama Selatan-Selatan dan Triangular Diresmikan", https://www.kominfo.go.id/conten t/detail/4778/kaa-kerja-samaselatan-selatan-dan-triangulardiresmikan/0/sorotan_media diakses pada tanggal 11 Mei 2019, pukul 08:47 WIB.

Kementerian Perencanaan Pembangunan Nasional/Badan Perencanaan Pembangunan Nasional (2014) "Rencana Pembangunan Jangka Menengah Nasional 2015-2019”, http://www.bpkp.go.id/public/upl oad/unit/sesma/files/Buku\%20I\% 20RPJMN\%202015-2019.pdf, diakses pada tanggal 26 Maret 2017, pukul 15:21 WIB.

Organizations of Economic Cooperation and Development (2016) "Aid at a Glance Charts", www.oecd.org/dac/stats/aid-at-aglance.htm diakses pada tanggal 3 Mei 2019, pukul 10:21 WIB.

Organizations of Economic Cooperation and Development (2018a) "GeoBook: Geographical Flows to Developing Countries",
https://stats.oecd.org/Index.aspx? DataSetCode $=$ DACGEO diakses pada tanggal 3 Mei 2019, pukul 12:05 WIB.

Organizations of Economic Cooperation and Development (2018b) "Development Cooperation Report 2018", https://www.oecdilibrary.org/docserver/dcr-2018en.pdf?expires $=1558777395 \& \mathrm{id}=\mathrm{i}$ $\mathrm{d} \&$ accname $=$ guest\&checksum $=\mathrm{D}$ 28AFA992CF18995CDE3282078 01D4D7 diakses pada tanggal 8 Mei 2019, pukul 14:27 WIB.

Organizations of Economic Cooperation and Development (2016b) "Providers of Development Co-operation beyond the DAC: Trends and Profiles", Development Cooperation Report 2016, pp. 279303.

The Jakarta Post (2014) "RI 10" ${ }^{\text {th }}$-largest Economy: WB", https://www.thejakartapost.com/n ews/2014/05/05/ri-10th-largesteconomy-wb.html diakses pada tanggal 7 Mei 2019, pukul 14:17 WIB.

The Jakarta Post (2015) "Indonesia Sends Aid to Vanuatu", www.thejakartapost.com/news/20 15/04/04/indonesia-sends-aidvanuatu.html diakses pada tanggal 12 Oktober 2016, pukul 13:47 WIB.

Trinidad, Dennis D (2014) "SouthSouth Cooperation in Southeast Asia and the Role of Japan", V.R.F. Series, No. 489, pp. 1-89.

Varqa, Sathia (2017) "Essential Palm Oil Statistics", http://www.palmoilanalytics.com/ files/epos-final-59.pdf diakses pada tanggal 10 Mei 2019, pukul 09:08 WIB. 
World Bank (2018) "Indonesia GDP Growth (Annual \%)", https://data.worldbank.org/indicat or/NY.GDP.MKTP.KD.ZG?locati
ons=ID\&start $=2008$ diakses pada tanggal 7 Mei 2019, pukul 12:19 WIB 